\title{
ESSAY: FAMILY LAW AND CIVIL UNION PARTNERSHIPS - STATUS, CONTRACT AND ACCESS TO SYMBOLS
}

\author{
Graeme W Austin*
}

This essay locates New Zealand's civil union legislation within the dynamic between "status" and "contract" that animates modern family law. "Status" concerns who we are; "contract" concerns the transactions we can enter. Because family law is concerned with affective relationships, it cannot apprehend people only as the atomised individuals anticipated by the modernist emphasis on contractual relations. Family law acknowledges the relevance to legal issues of "messy" issues of personality. Among the most complex and powerful aspects of personality with which the law concerns itself is love. Love affects who we are and law affects what love can be. Law provides and constrains the symbolic repertoire that helps organise the way we think about our affective relationships. The enactment of civil union legislation was an enormously positive step. However, by continuing to deny homosexuals the ability to marry, the New Zealand state persists in denying homosexuals a key part of the symbolic repertoire that is relevant to the way people in love can conceptualise their relationships. The transactions the state permits us to enter, particularly transactions that are expressions of love, affect the construction of our identities, illustrating once again the deep links that exist between who we are and the contracts we can enter.

\section{INTRODUCTION}

Family law fits awkwardly with historical narratives that portray the "movement" in progressive societies as being "from status to contract". ${ }^{1}$ Expanding on the thesis expounded in Sir Henry Maine's 1861 Ancient Law, ${ }^{2}$ Professor Graveson writes: "The rights and duties, capacities and

* J Byron McCormick Professor, James E Rogers College of Law, University of Arizona. Thank you to Elisabeth McDonald and Dean Knight for their kind invitation to participate in this symposium, to Dean Toni Massaro, Professor Barbara Atwood, Professor Bill Atkin, Geoff McLay and the anonymous reviewer for their helpful comments on an earlier draft. (C) Graeme W Austin, 2006.

1 Henry Sumner Maine Ancient Law: Its Connection with the Early History of Society and Its Relation to Modern Ideas / with introduction and notes by Sir Frederick Pollock (John Murray, London, 1930) 182.

2 Maine, above $\mathrm{n} 1$. 
incapacities of the individual are no longer being fixed by law as a consequence of his membership of a class: but those former incidents of status are coming more and more to depend for the nature and existence upon the will of the parties affected by them."3 Whereas in medieval law "what a man had largely determined what he was", ${ }^{4}$ modernism tends to deemphasise status and focuses rather more on transactions between autonomous individuals. ${ }^{5}$ For family law, the progression narrative distils at least two problems. First, while much of family law does concern the implications of transactions - marriages being the predominant type - family law often tacitly acknowledges problems with the premise of "autonomy" that animates the contract model. Family law has long been concerned with identifying who can consent, and to what one can consent. ${ }^{6}$ Secondly, the explanatory force of the progression narrative is belied somewhat by the importance of affective relationships in most people's lives. Most of us are deeply involved in relationships with others - we are sons, daughters, wives, parents, lovers, husbands, significant others, members of iwi and hapu, and, now, civil union partners ${ }^{7}$ - relationships that, to some extent at least, sublimate our autonomy. Some of these relationships involve contract, but all involve status. They often involve powerfully irrational bonds with others, bonds that make us quite unlike the atomised individual envisaged by the contract side of the progress narrative. ${ }^{8}$

3 R H Graveson Status in the Common Law (Athlone Press, London, 1953) 34.

4 Holly Brewer By Birth or Consent: Children, Law \& the Anglo-American Revolution in Authority (University of North Carolina Press, Chappell Hill, 2005) 6.

5 As Professor Robert Gordon suggests, Maine's analysis contributed to a programmatic view of legal history: "[T]he natural and proper evolution of a society (or at least of a progressive society, to use Maine's qualification) is toward the type of liberal capitalism seen in the advanced Western nations (especially the United States), and the natural and proper function of a legal system is to facilitate such an evolution." Robert M Gordon "Critical Legal Histories" (1984) 36 Stan L Rev 57, 59 (footnote omitted).

6 See Thomas Holland The Elements of Jurisprudence (Clarendon, Oxford, 1880) 135, for an early elaboration of this point. Holland would confine the "law of persons" to persons with "abnormal Personalit[ies]" - that is, persons without full capacity to consent. See further Part II Status and Contract in Family Law.

7 All of these status categories are recognised in different ways and in different contexts in New Zealand law. However, the meaning I accord to "status" in this essay is not limited to legal status. Indeed, one of my aims is to encourage more capacious thinking about status categories in legal discourse. The sense of status with which I am concerned here are those aspects of our personalities that make us unlike the rational, welfare maximizing individual that inhabits most other areas of law. In feudal systems, status denotes the individual's position in a pre-determined legal order - that is, the bonds that were imposed upon the individual by birth. Here, I pursue a meaning of status that emphasises affective bonds between people that is, status denotes legal relationships animated, ideally, by love.

8 By identifying the importance of the irrationality of affective bonds, I am not advocating a suspension of judgment about the emotions that catalyze and nurture our relationships with others. As scholars such as Martha Nussbaum have urged, emotions can productively be subject to normative scrutiny: see for example Martha Nussbaum Hiding from Humanity, Disgust Shame and the Law (Cambridge University Press, Cambridge, 2004). Many of those involved in the New Zealand family court system - counsellors, judges, 
Love affects who one is. Law, in turn, affects what love can be. Modern family law is as much concerned with issues arising from these loving connections with others as it is with mediating deliberative transactions between people in family relationships, and status continues to be among family law's principal concerns. If we broaden our understanding of status to at least include those things about us that give us the capacity to love, to enter into and nurture affective bonds, and if we acknowledge the importance of those bonds to who we are and the way we organise our lives, then we see that the individual has neither normatively nor descriptively (pace Maine) ${ }^{9}$ been "substituted for the Family, as the unit of which civil laws take account." 10

New Zealand's civil union legislation helps illuminate family law's amalgam of status and contract concerns. From one perspective, the advent of civil unions seems to exemplify Maine's model: formerly, a homosexual ${ }^{11}$ could not consent to enter into anything resembling formal marriage with another homosexual. ${ }^{12}$ A status - which can perhaps here be denoted as "a homosexual who wants to marry somebody of the same sex" - impinged upon contractual freedom. With the passage of the legislation, that particular status is somewhat less determining of the contracts homosexuals can enter: the Civil Union Act 2004 provides a new kind of state-sanctioned contract to which homosexuals can consent. For heterosexuals, New Zealand's civil union

and, sometimes, lawyers - do a lot of enormously productive work with family law clients of exactly this type: helping people gain better perspectives on the kinds of emotional commitments that caused them to become involved with the family law system.

9 It is important to acknowledge here that Maine probably would not have included status derived from marriage in his concept of status. See Graveson, above n 3, 36 (suggesting that Maine meant to exclude from the concept of status "those personal conditions which resulted, immediately or remotely, from agreement", including marriage). Doubtless decontextualised from Maine's original meaning, the progression narrative represented by his observation that law in modern societies has progressed "from status to contract" has become an important organising principle for thinking about the law's interaction with human relationships: see for example Brewer, above $\mathrm{n} 4,6$. It is used here in this more generalised sense.

10 Maine, above n 1, 180. ("[T]he movement of the progressive societies has been uniform in one respect. Through all its course it has been distinguished by the gradual dissolution of family dependency, and the growth of individual obligation in its place. The Individual is steadily substituted for the Family, as the unit of which civil laws take account.")

11 Recognising that the categories of "homosexual" and "heterosexual" are contested (as, of course are the categories "sex" and "gender") and subject to much important scholarly debate (see for example Annamarie Jagose Queer Theory (An Introduction) (New York University Press, New York, 1994)), I do not enter those debates here. For present purposes, it will suffice to characterise a homosexual as somebody whose erotic attentions are directed at people of the same physical sex.

12 Perhaps they could, if both parties to a facially heterosexual marriage were closeted. Here, I am assuming that they are not. As Graham Robb explains, entry to such marriages was once prescribed as a cure for homosexuality: Graham Robb Strangers: Homosexual Love in the $19^{\text {th }}$ Century (W W Norton \& Company, New York, 2004) 73-74. Robb also describes the (rare) Victorian phenomenon of "lavender marriages" and cites the example of Vita Sackville West and Harold Nicolson: Robb, above n 12, 130. 
legislation also expands the repertoire of contracts they can enter. ${ }^{13}$ Of course, Parliament has not accorded homosexuals the same level of contractual freedom as heterosexuals: our status still precludes entry to traditional marriage under the Marriage Act 1955.

As this essay explores, one of the innovations accompanying the passage of civil union partnerships legislation is to give homosexuals the right to render up important parts of our autonomy. ${ }^{14}$ As in many other contexts, the law here is reactive: before one enters into a civil union partnership, love will have already done much to make one less - and much more - than an atomised legal subject. Even so, the legislation sanctioning this transaction remains important. First, it provides practical support for parties to these relationships. ${ }^{15}$ Secondly, societal sanctioning is important for the symbolism it lends to loving relationships. Love does not stand aloof from society. Symbolic resources provided by the legal system - and, of course, by many other sources of meaning - alter what love can be and, in turn, on what we can be. In New Zealand, where the legal incidents attaching to formal marriage and civil union partnerships have been largely equalised, denying homosexuals the right to marry becomes most obviously and profoundly a denial of equal access to the symbolic resources from which people can construct who they are. Consequently, homosexuals' rights of citizenship are undermined by denying homosexuals the same access to the state-controlled symbolic order that heterosexuals currently enjoy. ${ }^{16}$

13 The situation is different in the United Kingdom, where the equivalent legislation precludes parties of different sex from entering into a civil partnership: see for example Civil Partnership Act 2004 (Eng \& Wales) s 3 .

14 This is even as the ability to enter into civil unions expands our autonomy; a point that underscores the complexity associated with the concept of autonomy itself. I am grateful to Professor Paula Baron for this observation.

15 This argument has also been made in the United States context: see William N Eskridge Jr "The Relational Case for Same-Sex Marriage" in Mary Lyndon Shanley (ed) Just Marriage (Oxford University Press, New York, 2004) 58,60. Eskridge suggests that governmental support of same sex relationships would contribute to the stability and endurance of those relationships.

16 Equal access to the symbolism associated with marriage was among the issues animating the advisory opinion of the Supreme Court of Massachusetts in Opinions of the Justices to the Senate (2004) 802 NE 2d 565 (Mass). A majority of the justicies considered that legislation banning the use of the term marriage by same sex couples conflicted with the equal protection and due process requirements of the Constitution of the Commonwealth and the Massachusetts Declaration of Rights (Opinions of the Justices to the Senate, 572). The Court expressly disagreed with the analysis advanced in a separate opinion authored by a minority of the justices that the label to be given by the Commonwealth of Massachusetts under proposed legislation to same and different-sex couples was immaterial (Opinions of the Justices to the Senate, 570 and fi 4). In New Zealand and elsewhere, the politics associated with state sanctioning of same-sex relationships are complicated because advocates of civil unions also denied that civil unions were the same as marriage. In this essay, I do not consider the reasons why opponents to same sex marriage in New Zealand persist in denying homosexuals the ability to marry. Here, my principal concern is to explore some of the implications of the enduring discriminatory effects of withholding from homosexuals the symbolism associated with marriage. For a comprehensive analysis of the politics behind the enactment of the civil 


\section{STATUS AND CONTRACT IN FAMILY LAW}

That modern law contains remnants of feudal status relationships is an important theme in recent family law scholarship. ${ }^{17}$ Such work reminds us that family law concerns both the contract and status aspects of the progression narrative. These reminders contrast with more familiar analyses of family histories that emphasise the change in the nature of marriage from feudal to companionate. ${ }^{18}$ Turning back to status is no retrograde step, however. Rather, status analyses in family law quite properly recognise all those messy aspects of personality that make us unlike the atomised legal subject envisaged by an emphasis on contract.

In recent work, Professor Holly Brewer examines the links between the movement from status to contract and the creation of legal categories of persons whose capacities to consent to contractual relations are called into question. ${ }^{19}$ Once society began to consider that birth and one's place in the feudal order did not dictate one's passage through life, and that free will could determine the character of much human interaction, the law needed to become concerned with who could give their consent and to what they could consent. For example, the capacity of children to consent was less of an issue when children slotted in to the divinely-sanctioned social order. In theory, no-one needed to consent to anything very much when the organisation of the world was pre-ordained. The capacity of children to consent to legal relations became an issue in Anglo-American legal and political thought as the tethers of feudal relationships were loosened. Brewer discusses how the breakdown of feudalism was accompanied by excruciatingly detailed - and often incomprehensible

unions legislation in New Zealand, see Nan Seuffert "Sexual Citizenship and the Civil Union Act 2004" (2006) 37 VUWLR 281.

17 See for example Mary Ann Glendon The New Family and the New Property (Boston, Butterworths, 1981) 226-236; Martha Minow Making All the Difference: Inclusion, Exclusion and American Law (Ithaca, Cornell, 1990) 128-130.

18 See generally Lawrence Stone Family Sex and Marriage in England 1500-1800 (Weidenfeld \& Nicholson, London, 1977). In this seminal work, Professor Stone describes the history of families in terms of a progression in differing stages from pre-modern societies based on blood ties, and ties to land, to companionate marriage in which the bonds of the nuclear family become more important than ties between the individual and their birth families. In turn, the aggregation of capital, typically derived from employment contracts, becomes more important than wealth derived from land. See also Stephanie Coontz Marriage: A History - From Obedience to Intimacy, or How Love Conquered Marriage (Viking, New York, 2005). A number of scholars have questioned Stone's thesis, primarily from normative, rather than descriptive perspectives, suggesting that it is by no means clear that most women were advantaged by the loosening of ties to their birth families in exchange for a stronger legal emphasis on companionate marriage. See for example Diane Johnson "In Love With Jane" (2005) 52(11) New York Review of Books, discussing the economic position of married women in eighteenth-century England.

19 See Brewer, above n 4. 
- rules about who could consent and to what they could consent. ${ }^{20}$ While children became a critical category of individuals whose ability to consent was called into question in Anglo-American thinking, other groups - such as women, slaves, vassals and the insane - were also categorised as lacking full, and sometimes all, capacity to enter into legal relations.

Mid $20^{\text {th }}$ century, Professor Keeton wrote that "[c]onsidered historically, family law began as a branch of public law, and only in recent times, whilst individualist theories have been dominant, has it become a branch of private law", ${ }^{21}$ a view that seems to emphasise horizontal relationships, with companionate marriage between equal individuals as the exemplar. Today, however, Mary Ann Glendon's suggestion that private law, including family law, is "not only shrinking: it is ... disappearing into an amalgam of law that is neither public nor private"22 seems more accurate, perhaps for private law generally, but certainly for modern family law. The amalgam's elements include issues and concerns associated with both status and contract. To be sure, emphasis on companionate marriage in modern family law thinking, and on capital derived from employment rather than land ownership, is consistent with the contract perspective. Much of family law is concerned with the consequences that flow from entering companionate marriage and other like relationships. But modern family law is also deeply concerned with those who are unable to consent; those who cannot participate fully in the social contract. Writing in the analytical jurisprudence tradition in the 1920s on the distinction between the law of persons and the law of things, Sir Thomas Holland would have severely limited the former category to cases of "abnormal" persons, "artificial persons, or infants, or under coverture, or convict or lunatic, and so forth, that the special effect upon the right in question of this abnormal personality has to be considered."23 These categories - "Abnormal Personalities" in Holland's taxonomy - are part of the modern inheritance of the breakdown of the feudal order that Brewer identifies. Modern legal heuristics denote artificial persons the concern of corporate and administrative laws, and criminology gets the convicts. Modern family law gets rather a lot of the rest. ${ }^{24}$ As a result, family law cannot apprehend people only as the atomised legal subjects associated with and produced by legal modernism.

20 See Brewer, above n 4, 150, instancing the case of Susannah Brown, who in 1784 was considered by Virginia judges to be too young to testify against the man who raped her, but was deemed old enough to consent to marrying the same man.

21 G W Keeton The Elementary Principles of Jurisprudence (London, Pitman, 1949) 328.

22 Glendon, above n 17, 226.

23 Holland, above n 6, 140.

24 We might speculate that family law's low status in the legal and professional academy is partly caused by its persistent concern with aberrant categories of persons, rather than legal relationships associated with things. Of course reasons for the low status of family law are complex (see Martha Minow "Forming Underneath Everything that Grows: Toward a History of Family Law" (1985) Wisc L Rev 819, 819) and may also have much to do with the gender of those who practise and write about it. Fortunately, we are currently 
To help illustrate these points, consider the welfare of a child aged eighteen months who is the subject of proceedings under the Care of Children Act 2004. It simply makes no sense for legal actors to think of the child as an autonomous individual. New Zealand family law is now quite detailed in its concern with the growing capacity of children to express their views about major issues that affect their welfare, and with the weight that legal decision makers should give to children's views. ${ }^{25}$

Perhaps more controversially, the recognition in the 2001 amendments to New Zealand's family property laws ${ }^{26}$ that "a just division of relationship property has regard to the economic advantages and disadvantages to the spouses or de facto partners arising from their marriage or de facto relationship or from the ending of their marriage or de facto relationship"27 can be understood as an acknowledgement of the inability of parties to relationships to organise their property interests as freely as if they were atomised individuals. A court can now award lump sum monetary awards or the transfer of other property where the court is satisfied that, at the end of the relationship, one party's financial position will be significantly better than that of the other party as a result of the division of functions within the relationship. ${ }^{28}$ The provisions now extend to civil union partnerships. ${ }^{29}$

Current jurisprudence under these new provisions is in some disarray, ${ }^{30}$ in large part because of the lack of clarity in some of the key statutory provisions. ${ }^{31}$ As Professor Bill Atkin points out, this

witnessing a resurgence in scholarly interest in family law and an accompanying rise in its importance within the legal academy.

25 The recently enacted Care of Children Act 2004 does give greater emphasis to the views of children than under previous enactments. Nevertheless, the views of very young children need to be given appropriate weight by legal decision makers. See for example $M M v D M$ (2005) 24 FRNZ 389, 397 Burns J, where Burns J quoted with approval the observations of Doogue J and Alastair Logan in "Care of Children Act 2004" (NZLS Seminar Paper, May 2005) that: "The court's obligation to ascertain the wishes of the child remains mandatory. Section 6(2)(b) omits the words 'take account of them to such extent as the court thinks fit, having regard to the age and maturity of the child'. As to whether this signifies an elevation of wishes over best interests has been debated. In our view guidance can be gleaned from [Re R (30 July 2004) HC AK CIV131/98, Kean J and $H v H$ (5 November 2004) FC WN FAM-2003-085-2591, Ullrich J.] The injunction to the court is that the child's views must be taken into account. Weight is for the Court. Age and maturity will continue to be factors in the court's assessment of the weight to be attached to the views expressed by a child."

26 Property (Relationships) Amendment Act 2001.

27 Property (Relationships) Amendment Act 2001, s 1N.

28 Property (Relationships) Amendment Act 2001, ss 15 and 15A.

29 Property (Relationships) Amendment Act 2005, s 3(3).

30 Bill Atkin "The Disparity in Economic Disparity: The Need for a full-scale Overhaul of ss 15 and 15A and Maintenance" in New Zealand Law Society The New Era: Professionalism in the Family Court (Conference Proceedings, Wellington, 2005) 207. 
may also be due to the conceptual difficulties with linking future financial needs with shares of property, rather than income. ${ }^{32}$ Perhaps more profoundly, the awkwardness of these new provisions may be symptomatic of more general difficulties associated with viewing parties to relationships in terms of both their agency and their lack of agency. People freely enter into the kinds of relationships with which the legislation is concerned, but those involved in those relationships cannot be relied on to look after their individual economic interests. The insistence in the 2001 provisions that the relevant disparities in income be both significant and an effect of the division of functions within the relationship distils difficult questions relating to the extent to which one's individuality and agency are sublimated by one's status as a party to a marriage, de facto relationship, or civil union partnership. ${ }^{33}$ The legislation specifically identifies only one relationship "effect" to which courts may have regard: "[T]he ongoing daily care of any minor or dependent children [of the relationship]." ${ }^{14}$ For the most part, courts are directed to consider "any other relevant circumstances." 35 This very loose structure implies that there is something about these kinds of affective relationships themselves that warrants the law's intervention. The 2001 amendments to New Zealand's relationship property law further extend the principle that people in love cannot be relied upon to act like the self-regarding liberal legal subjects. Society and the law struggle when rigid rules give way to more flexible discretions in order to accommodate the human condition, ${ }^{36}$ especially in contexts where the need to do so is prompted by something as messy as love.

We are here a long way from Maine's original scheme. In the middle of the last century, Professor Graveson suggested that Maine would have excluded from his concept of "status" personal conditions that result immediately or remotely from agreement, including marriage. ${ }^{37}$ The

31 See for example Nation v Nation [2005] NZFLR 103, para 162 (CA) Hammond, William Young and O'Regan JJ for the Court: "[T]his is the conceptual problem whether the provisions are properly to be regarded as being directed to economic equalisation in the larger sense of that term, on the breakdown of the relationship; or whether they are to be regarded as being directed to the loss of opportunity (by way of earning capacity) that one party has had to embrace by reason of the division of functions in the relationship. There are then the consequential problems of the appropriate ways of calculating awards."

32 Atkin, above n 30, 211.

33 We probably would not want it any other way: society depends on the kinds of other-regarding instincts and behaviours that characterise loving relationships. That is, the bonds of love cause much useful societal work - raising children, looking after the elderly and so on.

34 Property (Relationships) Amendment Act 2001, s 15.

35 Property (Relationships) Amendment Act 2001, s 15.

36 For a brilliant exposition of the dynamism between rigid rules and more flexible principles, and the rhetorical importance of both categories, see Carol M Rose "Crystals and Mud in Property Law" (1988) 40 Stan L Rev 577.

37 Graveson, above n 3. 
categories of status and contract nevertheless remain helpful, even if we recognise that they are not hermetically sealed from each other. ${ }^{38}$ To more fully apprehend the concerns of modern family law we need to broaden our understanding of status from the original sense in which Maine used it; at least to include status relationships that arise partly from choice, as well as those involving relationships into which we are born. Indeed, this broader sense of status is how Maine's model has been invoked more recently by leading family law thinkers. ${ }^{39}$ Professor Mary Ann Glendon, for instance, has in her work on family law ${ }^{40}$ and rights theory generally ${ }^{41}$ urged that the law needs to be more concerned than it is currently, both normatively and descriptively, with what she calls "ecologies" of family and other bonds. The shrinking of private law as a matter of scholarly concern, or, at least, the increasing tendency to meld private and public law concerns in analysis of legal and social phenomena, reflects a growing appreciation that public law, so important to issues of status, sets the background conditions for the social contract. ${ }^{42}$

But to view marriage, de facto relationships and civil unions solely as freely-willed agreements entered into between autonomous individuals captures only part of their reality. Love and, yes, sex, render people quite unlike modernism's reasoning subject. It is perhaps no accident that imagery associated with love and lust traditionally emphasises both foolishness and thraldom. As Holly Brewer's work reminds us, even after the breakdown of the feudal order, fools and prisoners had limited contractual capacity; limited capacity, in other words, to consent. When people talk about their partners - assuming, of course, that the relationship is intact - they frequently use language suggesting that being together is beyond the individual's control: "we are crazy for each other"; "it was meant to be"; "we were drawn to each other"; "together we make each other whole" and so on. Plato's depiction of love animating one's search for one's "other half" still resonates today. ${ }^{43}$ It is

38 Citing the example of inheritance laws, Max Weber considered that the contrast between status and contract-based societies was "only relative", and pointed out that though inheritance is the most important modern survival of modes of acquisition associated with status, inheritance rights can be determined contractually. Weber also cites the advent of pre-marriage property settlements as indicative of this interplay between status and contract-based acquisition of property rights. See Max Weber On Law in Economy and Society (Reinstein trans, Cambridge, Harvard University Press, 1954) 101-102.

39 See for example Minow, above n 24; Glendon, above n 17.

40 Glendon, above $\mathrm{n} 17$.

41 See generally Mary Ann Glendon Rights Talk: The Impoverishment of Political Discourse (Free Press, New York, 1993); Mary Ann Glendon A World Made New: Eleanor Roosevelt and the Universal Declaration of Human Rights (Random House, New York, 2002).

42 Drucilla Cornell The Imaginary Domain: Abortion, Pornography \& Sexual Harassment (Routledge, London, 1995) 12: "We judge public law by the 'as if' of a postulated original contract ... . [A] rightful law is one that all citizens, regarded as free and equal could have agreed to if they were in a position to actually consent within the general will" (footnote omitted).

43 The reference is to Aristophanes' speech in The Symposium, in which Aristophanes recounts that "the primeval man was round, his back and sides forming a circle; and he had four hands and four feet, one head 
revealing that one of the most privileged kinds of relationship between adults - romantic love leading to a life-time partnership - which is characteristically described as providing the foundation for western society, is described in terms that hark back to pre-modern status relationships. As many people find out to their cost, when in the throes of love it is often a bad time to be making important decisions, including, perhaps especially, those decisions with major economic effects.

The genius of family law, part of what marks out its unique terrain and justifies its heuristic separation from other areas of law, is that it is prepared to engage with aspects of our lives that result from affective bonds between one another; aspects of our lives that contest the descriptive and analytical capacity of legal modernism's atomised individualism. Family law is - and must continue to be - concerned with what gives us the capacity to form and nurture affective bonds with others, as well as with the implications of those bonds. The sense of "status" with which family law needs to be concerned involves many of those aspects of our humanity that make us unlike the dehumanised, rational entities valorised by some contractarian perspectives. Holland may have seen the focus of the status side of the equation, then characterized as the "law of persons", as being only about "Abnormal Personalities." Family law, perhaps more than any other area of legal activity, recognises the sense of stripping away the adjective; it concerns itself self-consciously with "personality", whether abnormal or not. For the purposes of family law at least, the law's understanding of status might productively be broadened to include all those aspects of self that make us unlike the liberal legal subject.

\section{CIVIL UNION STATUS}

What insights about New Zealand's civil union partnership laws might these frameworks offer? At first blush, the ability to enter into civil union partnerships seems consistent with the progression narrative. Prior to the Civil Union Act 2004 homosexuals' capacity to consent was more limited than heterosexuals' - as was the capacity of parties to heterosexual de facto relationships who did not want to marry. Like heterosexuals who did not want to marry, homosexuals simply did not have a state-sanctioned contract affirming bonds of love to which we could consent. Before civil unions and the accompanying consequential amendments to numerous other Acts, marriage gave heterosexual couples - and heterosexuals only - a way to signal their consent to legal rules governing relationships. Until the Civil Union Act 2004, homosexuals had no equivalent. To be sure, a homosexual couple could sit down with a lawyer and try to nut out a contract that did much

with two faces, looking opposite ways, set on a round neck and precisely alike; also four ears, two privy members, and the remainder to correspond. He could walk upright as men now do, backwards or forwards as he pleased, and he could also roll over and over at a great pace, turning on his four hands and four feet, eight in all, like tumblers going over and over with their legs in the air; this was when he wanted to run fast." Zeus cut this man in two. Love animates one's search for one's lost half. See Plato The Symposium MIT Internet Classics Archive <http://classics.mit.edu/Plato/symposium.html > (last accessed 15 June 2006). 
of what is currently achieved by marriage; even so, such contracts would lack the full societal imprimatur offered by a state institution.

Prior to the passage of the civil union legislation, homosexuals were in this aspect of our lives more like Holland's "Abnormal Personalities", or the categories of persons labouring under contractual incapacities identified by Brewer and others. Heterosexuals were better off: assuming they wanted to marry, they, at least, could consent to something that came with at least the symbolic benefits of state imprimatur and, for many, a number of practical benefits. Indeed, before civil unions, the law sometimes accorded adult partners a kind of pre-ordained status, at least with respect to their property interests. Through the 1980s and 1990s, Equity developed a number of principles that filled the gaps left as a result of the exclusion of de facto couples, whether heterosexual or homosexual, from New Zealand's matrimonial property regime. ${ }^{44}$ Equity came very close to suggesting that a legitimate expectation to a share of relationship property arose by dint of the relationship itself. ${ }^{45}$ That is, significant property consequences followed from being in a de facto relationship, consequences that did not necessarily require any deliberative representation by either of the parties as to the sharing of property interests. Conceptually then, the Property (Relationships) Amendment Act of 2001 did not change very much when it brought de facto relationships heterosexual and homosexual - within the matrimonial property regime that had been in place for married couples since $1976,{ }^{46}$ although the new law does offer significant procedural advantages to de facto couples, and the benefits of strong statutory presumptions in favour of equal sharing of relationship property. ${ }^{47}$ Importantly, however, the civil union partnership legislation gives homosexuals the right to signal their consent to a particular legal order. ${ }^{48}$

At the same time, entry into a civil union involves giving up autonomy in important respects. In some aspects of one's life, the law deems civil union partners to be a "couple" for the purposes of legal relations. Under the Property (Relationships) Act 1976, for example, parties to civil unions do not have to prove that they are living together as a couple, as a factual matter. A "civil union

44 The development of equitable principles in this context is exhaustively explored in Bill Atkin Living Together Without Marriage (Butterworths, Wellington, 1991).

45 Nicola Peart and Graeme Austin "Equity in Family Law" in Andrew Butler (ed) Equity and Trusts in New Zealand (Brookers, Wellington, 2003) 1179.

46 Matrimonial Property Act 1976.

47 It is, of course, not a bad thing that the law should set defaults that protect parties to relationships other than marriage. People drift into relationships, and decisions about whether people should be required to contract in, or contract out, of legislative defaults in part reflect policy concerns about the fair distribution of legal services.

48 The specific contents of that order are now contained in the Relationships (Statutory References) Act 2005, which, together with a number of separate amendments to other legislation, attempts to make civil unions an equivalent status in law to marriage and de facto relationships. 
partnership" is a term of art; entry to a civil union provides an official signal that the partners to the relationship are no longer, for the purposes of key aspects of their lives, to be considered solely as individuals. Much of this could have been achieved by contract - but by no means all. This is, of course, what people supporting civil unions campaigned and fought for: equal citizenship involves being able to demand recognition by the state of one's connections with another on the same terms as others' like demands. ${ }^{49}$ This is the publici juris aspect of civil unions, ${ }^{50}$ an aspect that cannot be fully replicated by private law contractual relations. ${ }^{51}$ With civil union partnerships, the law makes available to homosexuals the ability to offer up to another person parts of our emotional and legal autonomy - to signal that, in law and in love, civil union partners are not in all aspects of their lives two "I's", but a "we".

49 Compare Nancy F Cott "Marriage and Women's Citizenship in the United States, 1830-1934" (1998) 103 Am Hist Rev 1440, in which Professor Cott notes the gender inequality in citizenship that once flowed from marriage in the United States: American women lost their citizenship as a result of marrying a foreigner. American men did not.

50 In the mid- $19^{\text {th }}$ century, a Kentucky court described the publici juris character of marriage in the following terms: "Marriage ... unlike ordinary or commercial contracts, is publici juris, because it establishes fundamental and most important domestic relations. And therefore ... [it] is regulated and controlled by the sovereign power of the State, and cannot, like mere contracts, be dissolved by the mutual consent only of

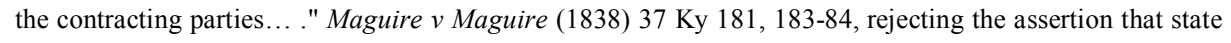
marriage laws are unconstitutional for interfering with contractual freedom.

51 Whereas equal citizenship includes equal access to state sanctioning of like relationships, free citizenship should be understood to involve the ability to be free from arbitrary state coercion in the character of those relationships. In an illuminating essay, Professor Franke notes that for former slaves in the United States, the right to marry was a treasured achievement in the antebellum era, and achievement that was linked to enhanced citizenship rights of African-Americans. Franke also argues, however, that equal access to marriage can involve coercive and normalising demands from the state, and insufficient recognition of, and antagonism towards other kinds of relationships. See generally Katherine M Franke "Becoming a Citizen: Reconstruction Era Regulation of African American Marriages" (1999) 11 Yale J L \& Human 251. Similar concerns fuelled debates surrounding the civil union legislation and campaigns for marriage rights for gay men and lesbians - that is, it was argued that achieving these rights would "domesticate" non-heterosexual relationships, and privilege further those that simulated traditional marriage, and marginalise those that do not. In contemporary New Zealand society, however, it seems that the government is committed to at least some pluralism in relationships the state will recognize, as is indicated by, for example, the recitation in the Property (Relationships) Act 1976 that the Act applies to parties to marriages, de facto relationships and civil unions. Furthermore, greater freedom will inevitably exist in societies such as New Zealand in which major social services are socialized: provision of basic needs, particularly health benefits, are generally much less tethered to one's relationships, for example. Accordingly, the state has less power to coerce people to enter into officially sanctioned kinds of relationships. 


\section{ACCESS TO SYMBOLS}

Apart from some enduring discrimination in the adoption context, ${ }^{52}$ the claim that civil unions provide their partners with a status that is legally inferior to marriage is difficult to sustain. Moreover, as Professor Nancy Polikoff has argued in the United States context, ${ }^{53}$ to even make such a claim might be accompanied by significant strategic risks. It could provide a basis for some decision makers - such as foster agencies, or courts in second parent adoption cases - to privilege married couples over parties to other kinds of relationships, which in turn risks entrenching the social and legal privilege accorded to traditional marriage. The discrimination that endures under New Zealand law is blatant, in that heterosexuals can do something - marry - that we cannot. But, in a legal environment in which civil unions provide almost all the rights and obligations of traditional marriage, we need to understand why this matters. The discrimination reveals itself more clearly, I believe, if we start to explore the various ways that symbols are important, and the law's role in organising the symbolic order.

The state can wield awesome power over our bodies, as Professor Kendall Thomas has brilliantly argued in his path-breaking analysis of the impacts of the criminalisation of sodomy. ${ }^{54}$ The state also wields power over our access to the symbolic order. As most people recognise, marriage is infused with symbolism. "Traditional marriage" is how marriage today is often described and few traditions exist in which symbols do not play a significant role. Civil unions are of course accompanied by much symbolism - and much of it associated with the state sanctioning of the relationship. It is possible, of course, that new traditions associated with civil union celebrations will develop: while civil unions are quite new, already they seem to allow scope for expressions of considerable creativity. Even so, marriage also remains an important source of symbols, and, so long as New Zealand law does not allow same sex couples to marry, these couples are locked out of an important resource for signalling the importance of their relationships. As the Supreme Court of Massachusetts recently said: "the decision whether and whom to marry is among life's momentous acts of self-definition." ${ }^{55}$ Civil union partners and parties to de facto relationships can decide to call what they have "marriage". Families, friends, loved-ones and the press can do the same. However, because marriage is a term of legal art - one is either married or not - the state retains a monopoly

52 Only "spouses" may adopt jointly: Adoption Act 1955, s 3(2)-(3). Family Court judges have disagreed as to whether "spouse" includes de facto couples. Compare for example In the matter of $R$ [1999] NZFLR 145 (FC) ("spouse" refers to a party to a legal marriage) with Re Adoption by Paul and Hauraki [1993] NZFLR 266 (FC) ("spouse" may include parties to a de facto relationship).

53 Nancy Polikoff "For the Sake of All Children: Opponents and Supporters of Same Sex Marriage Both Miss the Mark" (2006) 8 NY City L Rev 901, 912-921.

54 Kendall Thomas "Beyond the Privacy Principle" (1992) 92 Colum L Rev 1431. Professor Thomas has, however, argued against gay marriage: see Dwight Duncan "The Federal Marriage Amendment and Rules by Judges" (2004) 27 Harv JL \& Pub Pol'y 543, 567, reporting remarks by Professor Thomas.

55 Goodridge v Department of Pub. Health (2003) 798 NE 2d 941, 955 (Mass). 
power over the meaning of the term. By denying same sex couples the ability to marry, the state withholds the full symbolic significance of the term that can be invoked by and for heterosexual couples.

A number of legal scholars have explored the law's role in constructing the symbolic order. Critical legal theorists, for example, make much of law's constituting role - its ability to create reality by helping to determine what passes as common sense. "The legal forms we use", urges Professor Robert Gordon, "set limits on what we can imagine as practical options." 56 One of the most thorough analyses of the constitutive role of law has been by Professor Drucilla Cornell, whose work explores law's role in constructing what she describes as "the imaginary domain." 57 Cornell explores the contribution that the imagination makes to our sense of self and how the law creates the circumstances in which our imaginations can flourish, a project that in turn directs attention to legally-sanctioned impediments to the full flourishing of the imaginary domain. ${ }^{58}$ Other scholars, drawing on post-modernist perspectives, describe the human condition as involving a perpetual "dialogic" construction of the self and emphasise law's role in the provisions of "materials of culture" that fuel these processes. ${ }^{59}$ Such perspectives push beyond liberalism's concern with law's role in facilitating the kind of societal discourse that is a prerequisite for a free society. They are concerned with how the materials of culture available to us contribute to who we are - to the construction, to use their terminology, of the speaking subject. Who we are and controls over societal discourse are not, in other words, discrete issues. Societal discourse creates - "constitutes" the subject.

The following example may help illuminate some of these points. In $21^{\text {st }}$ century New Zealand, a plausible response to the question so frequently, and tediously, asked of homosexuals - "would you marry if you could?" - might be "how would I know?" Of course, many gay men and lesbians have well-formed, and highly informed, opinions on the issue of the right to marry and whether they as individuals would like to get married. But generation after generation of gay and lesbian children have been denied the ability to include "getting married" in their imagined futures. The ability to marry has not been part of who they are. Some might not "know" precisely because they have been

56 Gordon, above n 5, 111.

57 Cornell, above n 42.

58 For example, Cornell argues that the free availability of pornography impacts on women's imaginative domain by imposing a vision of women that crowds out other possibilities. Unlike some other scholars, Cornell does not argue for a banning of pornography: rather, she advocates legal techniques such as zoning rules that would limit pornography's impact on the imaginative lives of those who do not wish to apprehend it. See Cornell, above n 42, 95 .

59 See for example Rosemary J Coombe The Cultural Life of Intellectual Properties: Authorship, Appropriation, and the Law (Post-Contemporary Interventions) (Durham, Duke, 1998). 
unable to incorporate on the same terms as heterosexuals the symbolism associated with marriage either to accept or reject it - into their imaginative resources.

By precluding homosexuals from marrying, the government limits who we can be. By this, I do not mean merely that homosexuals cannot be "people who can marry." ${ }^{60}$ My concern is with the limiting effects of prohibitions on the symbols we can incorporate into our imaginative lives. Locking us out of marriage, the state tells us that we are not people whose sense of love and community might involve this kind of formal state-sanctioning of our love for another. Nor are we people who can reject this way of expressing love, for the ability to reject is premised on an ability to consent. With respect to marriage, homosexuals are like the prisoners, fools and children whose capacities to consent remained impeded by their status even after the break-down of the feudal order. The state also limits the stories we can tell about our lives, our imagined futures, the materials of culture we have available to us - out of which we can construct what love, and in turn what we, can be. ${ }^{61}$ At the very least, the law should ensure that arbitrary distinctions do not exist between the symbolic resources available to different sectors of society. ${ }^{62}$

60 For the reasons that Nancy Polikoff discusses, the energies of gay and lesbian advocates should be directed toward ensuring that all families are accorded dignity and given the same kind of support as families grounded in traditional marriage. See Polikoff, above n 53, 912-921.

61 An important difficulty with the lines of scholarship discussed in this Part is that they cannot yet theorise adequately the law's role in optimising the conditions for the flourishing of, to use Cornell's terminology, the imaginative domain. That is, less is typically said about how to optimize the availability of the materials of culture to ensure the fullest possible flourishing of the imaginative domain, the best sense of self. Here, it may be helpful to draw on the work of scholars, such as Professor Martha Nussbaum, who have devoted meticulous scholarly attention to bases for selecting between different visions for the good life. See Martha Nussbaum "Human Functioning and Social Justice: in Defense of Aristotelian Essentialism" (1992) 20 Pol Theory 202, 222.

62 Apparently, one does not need to be a postmodernist to recognise the cogency of the general concerns discussed here. Tacitly acknowledging the importance of civil unions to the symbolic order, a member of the Justice and Electoral Committee wrote, expressing a minority view, that the Relationships (Statutory References) Bill (the Bill that attempted to remove arbitrary distinctions between civil unions, de facto relationships, and marriages), "remains an affront to the dignity and freedom of New Zealanders who choose to marry and it trivialises the commitment of those who do marry." See Relationships (Statutory References) Bill 2005, no 151-2 (Justice and Electoral Committee report) 9 (minority views of Stephen Franks MP). The words Parliament uses, Mr Franks MP appears here to be suggesting, can implicate the dignity and freedom of heterosexuals who choose to marry. Symbols matter, in other words, to their sense of self. Predictably, Mr Franks MP gives rather less attention to how one might evaluate and compare the harms to married people he foresees with the psychic and other harm that might be imposed on other New Zealand citizens who are denied the right to marry or enter into other analogous relationships. The issue of comparison between state sanctioning of heterosexual and homosexual relationships also informed the advisory opinion of the Supreme Court of Massachusetts in Opinions of the Justices to the Senate, above $\mathrm{n}$ 16, 570, where the Court observed that legislation banning the use of the term "marriage" by same sex couples, accompanied by a provision banning discrimination against same sex couples who enter into a civil union under Massachusetts law, would create a legal "dissimilitude between the terms 'civil marriage' and 
Here, we have perhaps come full circle and can see again why family law's domain must amalgamate both status and contract. The question "how would I know?" is emblematic of possible effects on personality of the denial of the symbolic resources available from which one can construct one's worldview. ${ }^{63}$ This is of course not to suggest that New Zealand homosexuals would be unable to consent to marriage if the Marriage Act 1955 were amended this afternoon. Rather, it is to reinforce the idea that who we are affects what the transactions themselves mean.

\section{CONCLUSION}

There are, of course, many different and valid ways to love that do not involve marriage, and I do not wish to be interpreted as inaugurating or entrenching a view that love depends on marriage for its validation. My concern is with the symbolic resources available to homosexuals from which rich imagined lives can be created - so that homosexuals in the future need not answer "how would I know?" but can have available to them perspectives on affective lives that are informed by the same kinds of "knowledge" that are available to heterosexuals - that is, the same kinds of imaginative and discursive resources to which heterosexuals have access. While the state persists in denying homosexuals parts of the symbolic order that are relevant to what love can be and how it can be expressed, it imposes arbitrary limits on who we can be. In the terms of the general themes of this Symposium, this continues to burden our citizenship.

'civil union' [that] is not innocuous." As the Court observed, "it is a considered choice of language that reflects a demonstrable assigning of same-sex, largely homosexual, couples to second-class status."

63 To be sure, the law is only one source of symbolic resources. Legal change is possible because people have the courage to imagine futures beyond those imposed by law. This is an important reason why a number of legal scholars have been urging the use of literature and storytelling as part of the law school curriculum. See for example Kenji Yoshio "The City and the Poet" (2005) 114 Yale LJ 1835. 